\title{
USE OF RESIDUES OF FORESTRY EXPLORATION OF Pinus taeda FOR PARTICLEBOARD MANUFACTURE ${ }^{1}$
}

\author{
Setsuo Iwakiri ${ }^{2}$, Rosilani Trianoski ${ }^{2 *}$, Daniel Chies ${ }^{3}$, Everton Lorenzett Tavares $^{4}$, Morgana Cristina \\ França ${ }^{5}$, Pamela Caroline $\mathrm{Lau}^{4}$ and Viviane Teixeira Iwakiri ${ }^{6}$
}

\footnotetext{
${ }^{1}$ Received on 05.05.2016 accepted for publication on 16.03.2017.

${ }^{2}$ Universidade Federal do Paraná, Departamento de Engenharia e Tecnologia Florestal. E-mail: <setsuo@ufpr.br $>$ and $<$ rosillani@gmail.com>.

${ }^{3}$ Universidade Federal do Paraná, Madem SA. E-mail:<daniel@madem.com>.

${ }^{4}$ Universidade Estadual do Centro-Oeste, Programa de Pós-Graduação em Ciências Florestais. E-mail: <evertontavares1@hotmail.com> and <pamela.lau@hotmail.com>.

${ }^{5}$ Universidade Federal do Paraná, Programa de Pós-Graduação em Engenharia Florestal. E-mail:<morganaa_franca@hotmail.com>.

${ }^{6}$ Universidade Federal do Paraná, Programa de Pós-Graduação em Design. E-mail: <viviane_iwakiri@gmail.com>.

*Corresponding author.
}

\begin{abstract}
This study aimed to evaluate the quality of particleboards manufactured with forest exploitation waste from Pinus taeda. The material in the form of branches, tree tops, stumps and roots, was obtained from a forest plantation located in the Municipality of Mafra - SC. All the material was processed into wood chips for biomass and transported to the place of studies. The Pinus industrial particles were used as control and mixed with the waste in different proportions. The experimental plan consisted of the panels manufacture with $100 \%$ of each type of material and mixture of these com proportions of $75 / 25 \%, 50 / 50 \%$ and $25 / 75 \%$ with Pinus industrial particles, in addition to the mixture in equal parts, of the three types of materials. Experimental panels were manufactured with nominal density of $0.75 \mathrm{~g} / \mathrm{cm}^{3}$, using the urea-formaldehyde resin, in the proportion of $8 \%$ of solids - dry weight basis of the particles. The panels were pressed with specific pressure of $4.0 \mathrm{MPa}$, temperature of $160^{\circ} \mathrm{C}$ and pressing time of 8 minutes. The results of the internal bond tests met the requirements of the standard EN 312, is indicative that there has been a proper bonding of these particles originating forest exploitation wastes. General evaluations of the physical and mechanical properties results of the experimental panels indicate the possibility of use of particles obtained from branches, tree tops, stumps and roots, mixed com the industrial Pinus particles, in proportion of, up to, $50 \%$, for particleboard manufacture.
\end{abstract}

Keywords: Pinus particles; Panels pressing; urea-formaldehyde resin.

\section{UTILIZAÇÃO DE RESÍdUOS DE EXPLORAÇÃO FLORESTAL DE Pinus taeda PARA PRODUÇÃO DE PAINÉIS AGLOMERADOS}

\begin{abstract}
RESUMO - Esta pesquisa teve como objetivo avaliar a qualidade de painéis aglomerados produzidos com resíduos de exploração florestal de Pinus taeda. O material na forma de galhos e ponteiras e de tocos e raizes, foram obtidas de um plantio florestal localizado no Municipio de Mafra-SC. Todo o material foi transformado em cavacos para biomassa e transportados até o local de estudos. As partículas industriais de Pinus foram utilizadas como testemunha e em mistura com os resíduos em diferentes proporções. O plano experimental consistiu na produção de painéis com 100\% de cada tipo de material e em mistura destes com proporções de $75 / 25 \%$, 50/50\% e 25/75\% com partículas industriais de pinus, além da mistura em partes iguais dos três tipos de materiais. Foram produzidos painéis experimentais com densidade nominal de 0,75 $\mathrm{g} / \mathrm{cm}^{3}$, utilizando a resina uréia-formaldeído na proporção de $8 \%$ de sólidos - base peso seco das partículas. Os painéis foram prensados com pressão específica de 4,0 MPa, temperatura de $160^{\circ} \mathrm{C}$ e tempo de prensagem de 8 minutos. Os resultados dos ensaios de tração perpendicular atenderam aos requisitos da norma E 312 , sendo indicativo de que houve uma colagem adequada destas partículas provenientes de resíduos de exploração
\end{abstract}


florestal. Avaliações gerais dos resultados das propriedades físicas e mecânicas dos painéis experimentais indicam a possibilidade de uso de partículas obtidas a partir de galhos e ponteiras e de tocos e raizes em mistura com as partículas industriais de pinus na proporção de até $50 \%$ para produção de painéis aglomerados.

Palavras-Chave: Partículas de pinus; Prensagem de painéis; Resina uréia-formaldeído.

\section{INTRODUCTION}

The species of the genus Pinus and Eucalyptus, originating from forest plantations, are the basis of raw material for the particleboards manufacture in Brazil. Wood particles used in the panels composition are obtained from logs extracted within the commercial trees height. All the remaining material such as stumps, roots, tree tops and tree branches are considered wastes of exploitation and are left in the forests without a destination to take advantage of this woody material as industrial raw material.

Studies on potential of use of various types of waste wood, and products derived from wood, in particleboard manufacture have been objects of researchers in Brazil and other countries. Weber and Iwakiri (2015) assessed the feasibility of waste use from plywood panels processing, particle board and MDF in particleboard manufacture; Azambuja (2015) carried out studies on the potential use of civil construction and demolition waste as a raw material in the production of particleboards; Iwakiri et al. (2012) have evaluated the quality of particleboards manufactured with waste from sawmills in the Amazon region. The researchers found satisfactory results for the use of these residues in particleboard manufacture, indicating the possibility of its incorporation into the matrix of raw material for these industries.

There are wide sources of raw material with the possibility of use in particleboard manufacture, such as the various types of waste studied by these researchers. However, there are not in the literature, references about the use of exploitations wastes, such as stumps, roots, tree tops and tree branches for particleboards manufacture.

The wood's anatomical, physical and chemical properties are different among species and vary, also, among the trees and different parts of the same tree, which have a strong influence on the wood bonding process (Marra, 1992). Therefore, the woody material from stumps, roots, branches and tree tops, may present variations in physical and chemical properties resulting from the growing process.

Moslemi (1974) affirms that the choice of wood species for particleboard manufacture must be based on some important parameters such as density, $\mathrm{pH}$ and extractives. The wood

Revista Árvore. 2017;41(3):e410304 density is one of the basic requirements on the choice of species for production of particleboards, due to its influence on the compression ratio, which is the relationship between the panel density and the wood density. According to the author, the compression ratio must be at least 1.3 to ensure a proper contact area among the particles and to enough densification of the panel. Maloney (1993) states that, for panels of same density, which are manufactured with low density wood, they will present superior mechanical properties, however, their dimensional stability will be lower. Moslemi (1974) reports that the species with a density of, until, $0.55 \mathrm{~g} / \mathrm{cm}^{3}$, are the most suitable for production of particleboards, due to reaching a compression ratio between 1.3 and 1.6 .

Regarding the $\mathrm{pH}$ and woods extractives, Moslemi (1974) asserts that the same can directly influence the cure of the resin and, consequently, in quality of manufactured panels. The wood $\mathrm{pH}$ may vary from 3.0 to 5.5 and, according to Maloney (1993), wood with very acid pH may cause the pre-cure of the urea-formaldehyde resin in the phase of press closure, hindering the adhesion among the particles and reducing the properties of the panels. On the other hand, woods that have a slightly acidic $\mathrm{pH}$ require a little more of a catalyst to accelerate the cure of the urea-formaldehyde resin. As for the influence of extractives in the polymerization and adhesive cure, Maloney (1993) argues that, the wood with high content of extractives present difficulties for bonding, resulting in low resistance of the adhesive connection among the particles.

In view of the lack of information on the use of residues of forestry exploitation of Pinus taeda, like branches, tree tops and stumps with roots as a raw material in the production of particleboard, the objective of this work was to evaluate the quality of the panels manufactured with such wastes, in pure form and in mixtures with Pinus industrial particles.

\section{MATERIALAND METHODS}

\subsection{Material}

Woods originating forestry exploitation wastes from a plantation of Pinus taeda, located in the 
Municipality of Mafra - SC were used in this study. The materials in the form of stumps with roots, trees tops and branches, were removed from the area of harvest and processed in a chipper in the form of chips for biomass. Pinus taeda Industrial particles were obtained from the panelboards manufacture line and used as a control and in mixture with wastes particles from forest exploitation.

For the panels manufacture, urea-formaldehyde resin with solids content of $65 \%$, pH of 7.8 and a viscosity Brookfield $740 \mathrm{cP}$ was used. The ammonium sulfate was used as a catalyst to resin cure and paraffin emulsion as a moisture repellent.

\subsection{Preparation of particles and evaluation of their physical and chemical properties}

The material was received in the form of chips for biomass, being initially dried in the open air and, next they were sent for pre-drying in an oven and later for processing at the hammer mill for particulate generation. The particles were classified into sieves of meshes in 8 and 30 mesh and dried to the final moisture content of $3 \%$.

The specific bulk mass of particles derived from wastes and industrial particles, was determined by the weighing method of the material corresponding to the volume of a beaker of $1,000 \mathrm{ml}$. The $\mathrm{pH}$ and the content of total extractives were determined according to the procedures of the standards TAPPI,2002 and NBR,2002 respectively.

\subsection{Panels Manufacture and laboratory tests}

The panels were manufactured with a nominal density of $0.75 \mathrm{~g} / \mathrm{cm}^{3}$ and dimensions of $50 \times 38 \times 1.25 \mathrm{~cm}$, with different proportions of Pinus industrial particles, stumps and roots and tree tops and branches, according to experimental design presented in Table 1.

The urea-formaldehyde resin, catalyzed with $2 \%$ of sulphate of ammonia, was applied on the particles in an amount of $8 \%$ solids in relation to its dry mass. It was applied, also, $1 \%$ of emulsion of paraffin. For the formation of the particles mat a forming open box was used with dimensions of $50 \mathrm{~cm} \times 38 \mathrm{~cm}$. The panels were pressed at a temperature of $160^{\circ} \mathrm{C}$, specific pressure of 4.0 MPa and pressing time of 10 minutes. Three panels per treatment were manufactured, for a total of 30 panels.

After pressing, the panels were squared and packaged in climatic chamber with a temperature of $20+2{ }^{\circ} \mathrm{C}$ and a relative humidity of $65+5 \%$, until their stabilization to the average moisture content of $12 \%$.
For evaluation of the physical and mechanical properties, five specimens were removed from each panel for testing the apparent density, five for water absorption and thickness swelling, after 2 and 24 hours of immersion in water, five for static bending and five for internal bond. The tests were based on the procedures described in the standards EN 323 (2003), EN 317 (2003), EN 319 (2003) and EN 310 (2003), respectively.

The statistical analysis was performed according to a completely randomized experimental design and the results were evaluated by means of the Bartlett test, analysis of variance and the Tukey test at the level of probability of $95 \%$.

\section{RESULTS}

\subsection{Physical and chemical properties of wood particles}

Table 2 shows the mean values of specific bulk density, $\mathrm{pH}$ and total extractives of industrial Pinus particles of and wastes particles.

The particles obtained from tree tops and branches had higher mean of specific bulk density and the industrial particles the lowest average among the three types of materials. These values should serve as references on the compression of the particles in the panel and may influence in their physical and mechanical properties.

Regarding the materials chemical analysis, the $\mathrm{pH}$ varied in the range from 4.27 to 4.56 being the lowest value obtained for stumps and roots and the highest values for the industrial particles of pinus. These values were very close to the average value of 4.52 obtained by Trianoski (2010) for Pinus taeda wood. As for the total extractives, the average values ranged from $3.14 \%$ to $5.14 \%$, being that the particles of stumps and roots showed a value well superior relative to the industrial particles and tree tops and branches.

\subsection{Physical Properties of the panels}

Table 3 presents the average values of densities of panels manufactured with different types of materials and their combinations.

The average values of panels densities ranged from $0.706 \mathrm{~g} / \mathrm{cm}^{3}$ for the panels manufactured with a 
Table 1 - Experimental chart.

Tabela 1 - Delineamento experimental.

\begin{tabular}{lcc}
\hline Treatment & Type of materials and mixtures & Proportion (\%) \\
\hline T1 - Pip & Pinus industrial particles & 100 \\
T2 - ST & Stumps and roots & 100 \\
\hline T3 - TB & Tree tops and branches & 100 \\
T4 - Pip/ST & Pinus Industrial particles + stumps and roots & $75 / 25$ \\
T5 - Pip/ST & Pinus Industrial particles + stumps and roots & $50 / 50$ \\
\hline T6 - Pip/ST & Pinus Industrial particles + stumps and roots & $25 / 75$ \\
\hline T7 - Pip/TB & Pinus Industrial particles + tree tops and branches & $75 / 25$ \\
T8 - Pip/TB & Pinus Industrial particles + tree tops and branches & $50 / 50$ \\
T9 - Pip/TB & Pinus Industrial particles + tree tops and branches & $25 / 75$ \\
\hline T10-Pip/SR/TB & Pinus Industrial particles + stumps and roots + tree tops and branches & $33 / 33 / 33$ \\
\hline
\end{tabular}

Table 2 - Average values of physical and chemical properties of the particles.

Tabela 2 - Valores médios das propriedades físicas e químicas das partículas.

\begin{tabular}{|c|c|c|c|}
\hline Material & $\operatorname{BDWP}\left(\mathrm{g} / \mathrm{cm}^{3}\right)$ & $\mathrm{pH}$ & Total extractives $(\%)$ \\
\hline Pinus industrial particles - Pip & 0.190 & 4.56 & 3.14 \\
\hline Stumps and roots $-\mathrm{SR}$ & 0.215 & 4.27 & 5.14 \\
\hline Tree tops and branches - TB & 0.259 & 4.54 & 3.78 \\
\hline
\end{tabular}

Table 3 - Average values of the panels density.

Tabela 3 - Valores médios da densidade dos painéis.

\begin{tabular}{|c|c|}
\hline Treatment & Density $\left(\mathrm{g} / \mathrm{cm}^{3}\right)$ \\
\hline T1 - Pip 100 & $0.718_{(5.49)} \mathrm{ab}$ \\
\hline $\mathrm{T} 2-\mathrm{SR} 100$ & $0.721_{(5.26)} \mathrm{ab}$ \\
\hline T3 - TB 100 & $0.715_{(5.43)} \mathrm{ab}$ \\
\hline T4 - Pip/SR 75/25 & $0.724_{(4.26)} \mathrm{ab}$ \\
\hline T5 - Pip/SR 50/50 & $0.715_{(6.81)} \mathrm{ab}$ \\
\hline T6 - Pip/SR25/75 & $0.732_{(4.78)} \mathrm{a}$ \\
\hline T7 - Pip/TB 75/25 & $0.710_{(4.83)} \mathrm{ab}$ \\
\hline T 8 - Pip/TB 50/50 & $0.744_{(5.34)} \mathrm{a}$ \\
\hline T9 - Pip/TB25/75 & $0.707_{(6.44)} \mathrm{ab}$ \\
\hline T10-Pip/SR/TB 33/33/33 & $0.706_{(4.60)} \mathrm{b}$ \\
\hline
\end{tabular}

mixture of three types of materials (T10) to $0.744 \mathrm{~g} /$ $\mathrm{cm}^{3}$ for the panels manufactured with mixture of industrial particles and tree tops and branches in the proportion of $50 \%$ each (T8), and the means were statistically different among themselves. There were no significant differences among the averages obtained for the other treatments.

There were small variations among the values of density, obtained for the panels and the calculated value of 0.75 $\mathrm{g} / \mathrm{cm}^{3}$. The differences observed between the treatments may be attributed to the loss of material during the formation of the panels and return in thickness after hot pressing followed by conditioning.

Revista Árvore. 2017;41(3):e410304
Table 4 shows the mean values of water absorption and thickness swelling after 2 and 24 hours of immersion in water of the panels.

The average values of water absorption after 2 hours of immersion ranged from $5.06 \%$ for panels manufactured with $50 \%$ of industrial particles and $50 \%$ of stumps and roots (T5) to 7,91\% for panels manufactured with $25 \%$ of industrial particles and $75 \%$ of stumps and roots (T6), being the means statistically different among themselves.

There were no significant differences between the panels manufactured entirely with different types of 
Table 4 - Average values of the physical properties of panels.

Tabela 4 - Valores médios das propriedades físicas dos painéis.

\begin{tabular}{|c|c|c|c|c|}
\hline Treatment & WA $2 \mathrm{~h}(\%)$ & WA $24 \mathrm{~h}(\%)$ & TS $2 \mathrm{~h}(\%)$ & TS $24 \mathrm{~h}(\%)$ \\
\hline T1 - Pip 100 & $5.61_{(26.29)} \mathrm{ab}$ & $23.89_{(18.37)} \mathrm{bc}$ & $20.05_{(19.23)} \mathrm{c}$ & $64.71_{(5.46)} \mathrm{cd}$ \\
\hline $\mathrm{T} 2-\mathrm{SR} 100$ & $6.76_{(19.88)} \mathrm{abc}$ & $26.98_{(11.17)} \mathrm{c}$ & $17.85_{(13.90)} \mathrm{abc}$ & $73.76_{(5.33)} \mathrm{e}$ \\
\hline $\mathrm{T} 3-\mathrm{TB} 100$ & $5.70_{(39.46)} \mathrm{ab}$ & $18.85_{(6.64)} \mathrm{a}$ & $14.62_{(17.33)}^{\mathrm{a}}$ & $51.49_{(12.23)} \mathrm{a}$ \\
\hline T4 - Pip/SR 75/25 & $5.77_{(17.37)} \mathrm{ab}$ & $22.32_{(7.18)} \mathrm{ab}$ & $18.32_{(11.26)} \mathrm{abc}$ & $60.53_{(7.17)} \mathrm{bcd}$ \\
\hline T5 - Pip/SR50/50 & $5.06_{(28.11)} \mathrm{a}$ & $22.26_{(10.79)} \mathrm{ab}$ & $17.03_{(17.38)} \mathrm{abc}$ & $59.86_{(9.36)} \mathrm{bc}$ \\
\hline T6 - Pip/SR 25/75 & $7.91_{(24.48)} \mathrm{c}$ & $22.57_{(13.72)} \mathrm{abc}$ & $18.01_{(10.96)} \mathrm{bc}$ & $67.30_{(8.76)} \mathrm{de}$ \\
\hline T7 - Pip/TB 75/25 & $6.89_{(21.79)} \mathrm{abc}$ & $22.52_{(14.87)} \mathrm{abc}$ & $18.82_{(17.86)} \mathrm{abc}$ & $60.72_{(13.51)} \mathrm{bcd}$ \\
\hline T8 - Pip/TB 50/50 & $6.70_{(18.58)} \mathrm{abc}$ & $20.65_{(17.74)} \mathrm{ab}$ & $15.71_{(23.50)} \mathrm{ab}$ & $54.30_{(11.28)} \mathrm{ab}$ \\
\hline T9 - Pip/TB 25/75 & $6.93_{(28.24)} \mathrm{abc}$ & $20.40_{(20.17)} \mathrm{ab}$ & $16.62_{(16.62)} \mathrm{ab}$ & $56.48_{(15.82)} \mathrm{ab}$ \\
\hline T10-Pip/SR/TB 33/33/33 & $7.40_{(20.27)} \mathrm{bc}$ & $21.79_{(18.91)} \mathrm{ab}$ & $\left.16.69_{(17.94}\right) \mathrm{abc}$ & $59.66_{(13.36)} \mathrm{bc}$ \\
\hline
\end{tabular}

materials (T1, T2, T3), with different proportions of mixture of industrial particles and tree tops and branches (T7, T8, T9), and also those manufactured with mixtures of three types of materials (T10). Concerning the mixture of industrial particles and trunks and roots, the panels manufactured with a proportion of 25 and $75 \%$, respectively, had an average value of water absorption statistically superior in comparison to the panels manufactured with a proportion of 50 and $50 \%, 75$ and $25 \%$.

For water absorption after 24 hours of immersion, the mean values ranged from $18.85 \%$ to panels manufactured with tree tops and branches (T3) to $26.98 \%$ for panels manufactured with trunks and roots (T2).

The panels manufactured with tree tops and branches (T3) had mean statistically lower than the panels manufactured with industrial particles (T1) and trunks and roots (T2), and statistically equal to other treatments. All treatments manufactured with wastes showed means statistically equal to or less in comparison to the control panels.

The average values of thickness swelling after 2 hours of immersion ranged from $14.62 \%$ to panels manufactured with tree tops and branches (T3) to $20.05 \%$ for panels manufactured with industrial particles (T1)

The panels manufactured with tree tops and branches (T3) had mean statistically lower than the panels manufactured with industrial particles (T1) and with their mixture with trunks and roots (T6), at the proportions of $25 \%$ and $75 \%$ respectively. There were no significant differences compared to other treatments.

For thickness swelling after 24 hours of immersion, the mean values ranged from $51.49 \%$ to panels manufactured with tree tops and branches (T3) to $73.76 \%$ for panels manufactured with trunks and roots (T2).
The panels manufactured with particles of tree tops and branches (T3) showed an average statistically equal to the panels manufactured with mixture of industrial particles and tree tops and branches, at the proportions of 50/50\% (T8) and 25/75\% (T9), and inferior to the control panels (T1) and all other treatments.

\subsection{Mechanical properties of the panels}

The Table 5, shows the mean values of internal bond (IB), modulus of elasticity (MOE) and modulus of rupture (MOR) of the panels.

The average values of internal bond ranged from $0.51 \mathrm{MPa}$ for panels manufactured with industrial particles (T1) to $0.70 \mathrm{MPa}$ for panels manufactured with mixture of industrial particles and tree tops and branches in the proportions of $50 / 50 \%$ (T8).

The panels manufactured with a mixture of industrial particles and tree tops and branches in the proportions of 50/50\% (T8) showed an average statistically equal to the panels manufactured with industrial particles and tree tops and branches in the proportion of 75/ $25 \%$ (T7) and a mixture of three types of materials (T10), and superior compared to all other treatments.

The average values of MOE ranged from 1.154 $\mathrm{MPa}$ for panels manufactured with tree tops and branches (T3) to $1.913 \mathrm{MPa}$ for panels manufactured with industrial particles (T1).

The panels manufactured with industrial particles and stumps and roots in the proportions of $75 / 25 \%$ (T4) and 50/50\% (T5) and panels manufactured with a mixture of particles industrial and tree tops and branches in the proportions of $75 / 25 \%$ (T7), showed average values of MOE statistically equal to the control panels. 
Table 5 - Average values of the mechanical properties of panels.

Tabela 5 - Valores médios das propriedades mecânicas dos painéis.

\begin{tabular}{|c|c|c|c|}
\hline Treatment & $\mathrm{IB}(\mathrm{MPa})$ & $\operatorname{MOE}(\mathrm{MPa})$ & $\operatorname{MOR}(\mathrm{MPa})$ \\
\hline T1 - Pip 100 & $0.51_{(12.79)} \mathrm{a}$ & $1.913_{(14.99)} \mathrm{e}$ & $10.3_{(19.99)} \mathrm{e}$ \\
\hline $\mathrm{T} 2-\mathrm{SR} 100$ & $0.59_{(12.71)} \mathrm{ab}$ & $1.341_{(13.56)} \mathrm{ab}$ & $8.3_{(15.37)} \mathrm{abcd}$ \\
\hline $\mathrm{T} 3-\mathrm{TB} 100$ & $0.59_{(16.86)} \mathrm{ab}$ & $1,154_{(21.82)} \mathrm{a}$ & $6.9_{(24.68)} \mathrm{ab}$ \\
\hline T4 - Pip/SR 75/25 & $0.54_{(15.25)} \mathrm{a}$ & $1.739_{(11.60)} \mathrm{de}$ & $8.8_{(19.95)} \mathrm{cde}$ \\
\hline T5 - Pip/SR 50/50 & $0.58_{(9.81)} \mathrm{ab}$ & $1.774_{(14.21)} \mathrm{de}$ & $9.5_{(22.03)} \mathrm{cde}$ \\
\hline T6 - Pip/SR 25/75 & $0.55_{(21.91)} \mathrm{a}$ & $1.440_{(15.68)} \mathrm{bc}$ & $9.1_{(19.05)} \mathrm{cde}$ \\
\hline T7 - Pip/TB 75/25 & $0.60_{(17.08)} \mathrm{abc}$ & $1.808_{(8.53)} \mathrm{de}$ & $10.0_{(11.20)} \mathrm{de}$ \\
\hline T8 - Pip/TB 50/50 & $0.70_{(8.37} \mathrm{c}$ & $1.589_{(11.06)} \mathrm{cd}$ & $8.5_{(15.81)}$ bcde \\
\hline T9 - Pip/TB 25/75 & $0.59_{(12.60} \mathrm{ab}$ & $1,286_{(13.11)} \mathrm{ab}$ & $6.6_{(20.91)} \mathrm{a}$ \\
\hline T10-Pip/SR/TB 33/33/33 & $0.69_{(17.77} \mathrm{bc}$ & $1,367_{(9.34)} \mathrm{abc}$ & $7.8_{(24.80)} \mathrm{abc}$ \\
\hline
\end{tabular}

The other treatments exhibited averages statistically lower in comparison to the control panels.

The average values of MOR ranged from $6.65 \mathrm{MPa}$ for panels manufactured with mixture of industrial particles and tree tops and branches at the proportions of 25/ $75 \%$ (T9) to $10.27 \mathrm{MPa}$ for panels manufactured with industrial particles (T1).

The panels manufactured with industrial particles and stumps and roots in the proportions of (T4, T5 and T6), besides panels manufactured with a mixture of industrial particles and tree tops and branches in the proportions of $75 / 25 \%$ (T7), and 50/50\% (T8) showed average values of MOR statistically equal to the control panels. The other treatments exhibited averages statistically lower in comparison to the control panels.

\section{DISCUSSIONS}

The lowest density of pinus industrial particles and consequent increase in the compression ratio of the panels did not influence the results of water absorption, thickness swelling and internal bond, but there was an increase in the values of MOE and MOR of the panels manufactured with such particles. Moslemi (1974) states that the larger the compression ratio, the greater the mechanical properties and thickness swelling of the panel will be. However, this relationship is valid considering that the density of solid wood, whose compression ratio should vary in the range of 1.3 to 1.6 for species listed as suitable for the production of wood particulate panels.

The $\mathrm{pH}$ and the concentrations of total extractives of different types of materials did not affect significantly the results of physical and mechanical properties of

Revista Árvore. 2017;41(3):e410304 the panels. The only exception was for the panels produced with particles of stumps and roots, whose content of extractives was the highest (5.14\%) and probably could have influenced the increase of swelling in thickness after 24 hours of immersion. The values of total extractives obtained in this research are inferior to $10 \%$ as referenced by Sjöström (1981). Fengel and Wegener (1989) claim that the range of variation in total extractives for conifers wood is $5 \pm 3 \%$.

The panels manufactured with particles of tree tops and branches showed better results of water absorption and thickness swelling, when compared to the control panels. The results also indicated the possibility of mixture of these materials with the industrial particles in particleboards manufacture.

The results of water absorption obtained in this study were satisfactory when compared to some of the references presented in the literature on experimental particleboards of species originating from forest plantations. Naumann et al. (2008) found, for particleboards of Eucalyptus urophylla and Schizolobium amazonicum, absorption values after 24 hours of $97.2 \%$ and $117.9 \%$, respectively. Iwakiri et al. (1996) found, for particleboards of Pinus taeda and Eucalyptus dunnii, water absorption values 24 hours of $75.04 \%$ and $80.05 \%$, respectively. Concerning the thickness swelling after 24 hours, the results obtained in this study were high when compared to values obtained by Naumann et al. (2008) for panels of Eucalyptus urophylla and Schizolobium amazonicum, of $30.50 \%$ and $35.09 \%$, respectively. Iwakiri et al. (1996) found for panels of Pinus taeda and Eucalyptus dunnii, values of $30.50 \%$ and $35.09 \%$.

All treatments met the requirement of standard EN 312 which specifies for internal bond a minimum value of 
$0.35 \mathrm{MP}$, indicating that there was a proper bonding of the particles deriving from these exploitation wastes and its viability for particleboard manufacture. When it comes to the tests of static bending, no treatment met the requirement of standard EN 312 for MOR, whose minimum value is $13 \mathrm{MPa}$. Whereas, for MOE, the mixtures of $25 \%$ to $50 \%$ of particles from trunks and roots and branches met the standard specifications of 1,600 Mpa.

Trianoski et al. (2011) found for particleboards manufactured with wood of Acrocarpus fraxinifolius, Melia azedarach and Toona ciliata, IB values of 1.50 $\mathrm{MPa}, 1.88 \mathrm{MPa}$ and $1.64 \mathrm{MPa}$, respectively. Colli et al. (2010) found for particleboards manufactured with Schizolobium amazonicum average value of $0.22 \mathrm{MPa}$. Whereas, Vital et al. (1974) found for particleboards of Virola spp., with compression ratio of 1.2:1.0 (low) and 1.6:1.0 (high), values of 0.48 MP and 0.65 MPa, respectively.

The results of MOR and MOE obtained in this study were satisfactory when compared to some of the results presented in the literature. Naumann et al. (2008) found for particleboards produced with wood of Eucalyptus urophylla and Schizolobium amazonicum, values of 4.26 MPa and 13.96 MPa for MOR and 696 $\mathrm{MPa}$ and $1.873 \mathrm{MPa}$ for MOE, respectively. Whereas, Trianoski et al. (2011) found for particleboards produced with wood of Acrocarpus fraxinifolius, Melia azedarach and Toona ciliata, MOR average of $18.19 \mathrm{MPa}, 18.56$ $\mathrm{MPa}$ and $19.83 \mathrm{MPa}$, and MOE average of $2.134 \mathrm{MPa}$, 2.191 MPa and 2.427 MPa respectively for the three studied species.

The results of the mechanical properties indicate the possibility of mixture of particles from trunks and roots and tree tops and branches in the proportion of up to $50 \%$ in mixture with the pinus industrial particles for particleboards manufacture.

\section{CONCLUSIONS}

The density, $\mathrm{pH}$ and the content of total extractives of particles from tree tops and branches and from stumps and roots did not influence, significantly on the properties of the panels.

The panels manufactured with particles from tree tops and branches showed better results of water absorption and thickness swelling, when compared to the control panels. The results also indicated the possibility of mixture of these materials with the pinus industrial particles in particleboards manufacture.

The results of internal bond, obtained for all treatments, complied with the minimum requirement of $0.35 \mathrm{MPa}$, as specified in standard EN 312, indicating that there was an adequate bonding of particles originating from these exploitation residues.

Based on the results, it is concluded that it is feasible the particleboard manufacture, with up to $50 \%$ of forestry exploitation wastes, in mixture with the industrial particles of pinus, bearing in mind that their properties meet the requirements from commercial standard EN 312. It is necessary, however, to evaluate the quantitative availability of these materials, operational and economic matters, so that the same can be incorporated into the raw material matrix of particleboards industries. The use of forest exploitation wastes, in the production chain of particleboards industries, will result in positive impacts in terms of optimization in the use of forest resources, generating social, environmental and economic benefits.

\section{ACKNOWLEDGEMENTS}

The authors express their thanks to the companies MADEM S.A. and HEXION Ltda., by the donation of wood and resins used in this research.

\section{REFERENCES}

Azambuja RR. Aproveitamento de resíduos de construção e demolição para produção de painéis aglomerados [dissertação]. Curitiba: Universidade Federal do Paraná; 2015.

Associação Brasileira de Normas Técnicas ABNT. NBR 14853. Determinação do material solúvel em etanol: tolueno e em diclorometano. São Paulo: 2002.

Colli A, Vital BR, Carneiro ACO, Silva JC, Carvalho ANML, Della Lucia RM. Propriedades de chapas fabricadas com partículas de madeira de paricá (Schizolobium amazonicum Huber ex. Ducke) e fibras de coco (cocos mucifera L.) Revista Árvore. 2010;34(2):333-8.

European Committee for Standardization. EN 310. Determination of modulus of elasticity in bending and of bending strength. Brussels: 2002. 
European Committee for Standardization. EN 312. Particleboards - Specifications. Brussels: 2003.

European Committee for Standardization. EN 317. Determination of swelling in thickness after immersion in water. Brussels: 2002.

European Committee for Standardization. EN 319. Determination of perpendicular tension stregnth. Brussels: 2002.

European Committee for Standardization. EN 323. Determination of board density. Brussels: 2002.

Fengel D, Wegener G. Wood chemistry, ultrastructure reactions. Berlin: 1989.612p.

Iwakiri S, Latorraca JVF, Silva DA, Gabardo JL,
Klitzke RJ, Fofano A. et al. Produção de chapas de Madeira aglomerada de Pinus taeda taeda elliottii (Engelm) and Eucalyptus dunnii (Maid). Agrárias. 1996;15:33-41.

Iwakiri S, Vianez BF, Weber C, Trianoski R, Almeida VC. Avaliação das propriedades de painéis aglomerados produzidos com resíduos de serrarias de nove espécies de madeiras tropicais da Amazônia. Acta Amazônica. 2012;42:59-64.

Maloney TM. Modern particleboard \& dryprocess fiberboard manufacturing. San Francisco: Miller Freeman;1993. 689p.

Marra AA. Technology of wood bonding: principles

Revista Árvore. 2017;41(3):e410304 